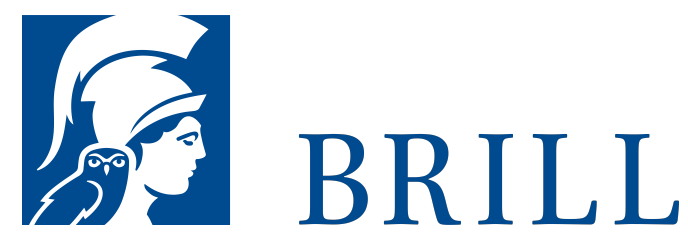

\title{
The Significant and the Insignificant
}

Five Studies in Herodotus' View of History

Author:J.E. van de Veen

Although it is widely recognised that Solon's thoughts on human life (1.30-32) are important to a correct understanding of Herodotus' work, little attention has been given to their narratological meaning. On the basis of a careful interpretation of five episodes, this monograph argues that Solon's advice, 'look to the end', establishes the viewpoint from which Herodotus' stories are to be understood. This viewpoint leads to surprising conclusions as to what is and is not important to the development of history. It casts doubts especially on the magnificent role of Athens and its democracy.

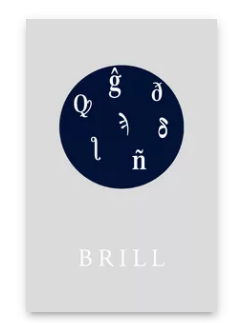

Pages: 154 pp.

Language:

English

Subjects: Greek

\& Latin

Literature,

Classical Studies

Publisher: Brill

Series:

Amsterdam

Studies in

Classical

Philology,

Volume: 6

E-Book (PDF)

Released online:

o1 Oct 2019

ISBN: 978-90-

04-40901-9

List price

USD $\$ 77.00$

Hardback

Publication date:

o1 Jan 1996

ISBN: 978-90-

50-63296-6

List price

USD $\$ 73.00$ 
For more information see brill.com

Order information: Order online at brill.com +44330 333 0049 | customerservices@brill.com Submission information: brill.com/authors

Titles published by Brill | Fink, Brill | mentis or Brill | Schöningh: +49(o)715413279216| brill@brocom.de 